\title{
A RESEARCH TO DETERMINE THE RELATIONSHIP BETWEEN THE ORGANIZATIONAL IDENTIFICATION OF THE EMPLOYEES IN TOURISM ESTABLISHMENTS AND THEIR TURNOVER INTENTION
}

\author{
Rüya Ehtiyar ${ }^{1}$ \\ Akin $\mathbf{A k s u}^{2}$ \\ Ömür Uçar ${ }^{3}$
}

\begin{abstract}
The purpose of this study is to reveal the relationship between the organizational identification of the employees in hotel establishments and travel agencies and their turnover intention. The research data were obtained from 275 participants working in hotels and travel agencies in Antalya. The data were analysed through descriptive analyses, and correlation and regression analyses. As a result of the analyses, it was found that there was a significant and negative relationship between the perceptions of the employees about the organizational identification and their turnover intention. As a result of the study, it was concluded that the organizational identification of the employees affected their turnover intention at a level of $5 \%$.
\end{abstract}

Keywords: Organizational Identification, Turnover Intention, Employees of Hotels and Travel Agencies.

\section{INTRODUCTION}

In today's business world, where change, uncertainty, risk and chaotic environment have emerged, it can be stated that organizations are trying to provide qualified labour force in order to reach their goals and to ensure the continuity of this work force in the establishment. In addition, employees change their jobs for various reasons and desire to be employed in the establishments where they can work in better conditions each time.

\footnotetext{
${ }^{1}$ Associate Professor, Akdeniz University Faculty of Tourism, Antalya, ehtiyar@akdeniz.edu.tr

${ }^{2}$ Professor, Akdeniz University Faculty of Tourism, Antalya, aaksu@akdeniz.edu.tr

${ }^{3} \mathrm{PhD}$ Candidate, Akdeniz University Social Sciences Institute, Antalya, ucar_omur@hotmail.com
} 
Before the employees leave their workplace, they begin to have an intention to do so. Turnover intention is a particular asset for the organization and the employee because of the importance of the long-term employment of the organizations and the fact that it is an important premise of the act to leave the job. This is because the next stage of turnover intention, which is to turn this intention into action, can have negative consequences for both employees and organizations (Ömüriş, 2014: 30). Barttlett (1999) refers to "a conscious and cautious decision or intention to leave the organization". Price (1977) defines the turnover intention as "the degree of individual movement within the boundaries required to be a member of a social system". Turnover intention is defined as the destructive and active actions that employees have shown when they are unsatisfied with their working conditions by Rusbelt et al. (1988). More specifically, turnover intention is a preliminary indication of the real absenteeism and imposes significant costs on establishments (Ehtiyar et al. 2010: 32, Tett and Meyer 1993: 259, Lambert et al. 2001: 245).

As a matter of fact, turnover intention is a concept which has received widespread attention in the organizational behaviour literature as a premise of the act to leave the job. The relevant literature reveals findings that turnover intention would adversely affect the effectiveness of an organization. (Aslan and Etyemez, 2015; Onay and Kılc1, 2011; Sabuncuoğlu, 2007; Gül et al., 2008; Schwepker, 2001). In this study, the concept of "turnover intention", which will be considered as the dependent variable, refers to "a conscious and cautious decision or intention to leave the organization" (Barttlett, 1999: 70). There are also organizational factors that can cause the turnover intention of the employees to decrease or not to develop. Organizational identification, which expresses the perceptions of the employees about their being one and similar with their organizations, is considered as one of these factors. What shows itself as an important role in the organizations' long-term successes is to make the organization membership an important part of the employees' egos and to make them proud while defining themselves as the members of the organization, in other words, to enable them to embrace the organization to the extent to which they identify their own identities with the organization itself (Polat \& Tabak 2009: 19). Organizational identification is the sense of unity and belonging that the employees feel towards their organizations.

The employees who are identified with their organizations find their work meaningful and thus get motivated. In other words, it expresses a biased, affective commitment of the employees (Buchanan, 1974: 533) to the aims and values of the organization, to their role and to the organization in relation to the realization of the goals and values. This is because, as a result of the identification, individuals feel emotionally happy and get attached to their organizations. Identification consists of three elements (Tosun, 1981: 145-150): The main element of identification is that 
the individual strongly believes in the goals and values of the organization and accepts them. The identification with this aspect can be seen as a process of an integration of the organizational and individual goals. The second element of identification is that the individual willingly performs the acts which form his or her organizational role. It is an important source of satisfaction to try to make the goals of the organization real for the individual who adopts them as if they were his or her own.

The third element of identification is that the individuals are willing to maintain their membership in the organization. Positive organizational identification reduces the labour turnover rate, decreases the level of group conflicts, and increases the employees' compliance, motivation, participation and job satisfaction (Vardaman et al., 2017; Sökmen and Bıyık, 2016; Rockman and Ballinger, 2017; Kesen, 2016; Başar and Basım, 2015). Members who are strongly identified with their organization accept the organizational goals as their personal goals and become more loyal and harmonious. Job performances of the individuals identified with their organizations increase as well (Şantaş et al. 2016). The relationship between identification and turnover intention was examined in various studies in the literature. It has been concluded that organizational identification is affected by turnover intention in the studies that determine the relationship between organizational identification and turnover intention (Turgut et al., 2017; Polat \& Meydan, 2010; Akgündüz \& Bardakoğlu, 2015; Turunç \& Çelik, 2015; Tolukan et al., 2016).

In brief, one of the critical success factors for the long-term achievements of the establishments is to ensure that the employees adopt the organizational goals and to mobilize the dynamics that will attach them to the organization. It is seen that it is very important for the employees to stay in the organization in terms of the fact that the human resource provides a competitive advantage to the establishments in tourism sector; however, despite this importance, when examined at the global level, it is seen that social and psychological problems increase in tourism establishments. Although the turnover intention of the employees has been studied in many studies (Bayarçelik and Fındıklı, 2017; Yenihan et al., 2014; Serçeoğlu et al., 2016; Güçer et al., 2017; Örücü and Özafşarlığlu, 2013), the number of studies examining the effects of the perception of organizational identification on turnover intention is limited, especially for our country. Therefore, the present study examined the relationship between the perception of the organizational identification, which is an extremely important concept in terms of organizational efficiency and effectiveness, and turnover intention. 


\section{METHOD}

\section{The Purpose of the Study:}

The main purpose of this study is to investigate the relationship between the organizational identification and the turnover intention of the employees who are employed in the hospitality industry. In addition, determining the extent to which organizational identification predicts the level of turnover constitutes another aim of this study.

\section{The Scope of the Study}

The population of this study is composed of the employees of the tourism establishments operating in Antalya region.

\section{The Method of the Study}

Convenience sampling method was employed while forming the study group. Convenience sampling method was used in order to reach the people to be included in the sample so as to keep the questionnaires' rate of return high. A total of 292 questionnaires were distributed between April and August, 2018. As a result of the analysis, a total of 275 questionnaires were considered valid to be included in the analyses due to the exclusion of the incomplete questionnaires. In the related literature, it is stated that the sample size for the analyses can be determined in proportion to the number of variables. Accordingly, the number of variables in normal distribution is recommended to be five, and a sample size that is ten times larger is suggested in other distributions (Bryman ve Cramer, 2001; as cited in Tavşanc1l, 2002). In this study, since the total number of items on the scales was 9, it can be stated that 275 samples were above the minimum number and sufficient.

The research analyses were conducted through three questionnaires. In the first part of the questionnaire, there are questions to determine the demographic characteristics of the employees. In the second part of the questionnaire, there are items to measure "Organizational Identification". The one-dimensional organizational identification scale with six items which was developed by Mael and Asforth (1992) and adapted to Turkish by Tüzün (2006) was used in the study. The cronbach alpha $(\alpha)$ coefficient of the organizational identification scale, which was adapted to Turkish and whose reliability and validity analyses were made, was found to be $=, 89$ in this study. In the third part of the questionnaire, the Turnover Intention Scale, developed by Camman et al. (1979), was used. In order to measure the level of employees' self-evaluation intentions to stay at work or to resign, the three-item Turnover Intention Scale, developed by Cammann, Fichman, Jenkins and 
Klesh (1979), was used. The cronbach alpha $(\alpha)$ coefficient of the turnover intention scale, which was adapted to Turkish and whose reliability and validity analyses were made, was found to be $=, 88$ in this study. Both of the scales were 5-point likert type ( 1 = strongly disagree, $5=$ strongly agree $)$.

\section{Hypotheses}

H1: There is a negative and significant relationship between the employees' perceptions of organizational identification and their turnover intention.

$\mathrm{H} 2$ : The employees' level of organizational identification significantly predicts their level of turnover.

\section{FINDINGS}

The findings obtained as a result of performing various statistical analyses on the data acquired by survey method are presented under the heading of demographic findings, and the descriptive statistics regarding the organizational identification of the employees and their turnover intention are given under the heading of correlation and regression analysis.

When the findings of the demographic variables were examined, a total of 275 employees of accommodation establishments and travel agencies participated in the study and $36.4 \%$ of them were female employees. A total of $46.9 \%$ of the participants were single and $54.50 \%$ of them were 31 years old or over. It was confirmed that $37.1 \%$ of the participants had undergraduate and graduate degrees and $49.1 \%$ of them had tourism education. In addition, it was concluded that $42.5 \%$ of the participants had one-year or less employment in the current establishment.

According to the results of the analysis given in Table 1, it can be stated that the turnover intention of the employees in the tourism establishments was below the average with 2,21 and the mean value for their organizational identification was above the average with 3,76. A negative and significant relationship was found between the employees' perceptions of organizational identification and their turnover intention. Therefore, $\mathrm{H} 1$ hypothesis was accepted. 
Table 1: Correlation Analysis of Organizational Identification and Turnover Intention and Their Mean Values

\begin{tabular}{|l|l|l|l|l|}
\hline & Mean & Std Dev & $\begin{array}{l}\text { TI } \\
\text { OVERAL } \\
\text { L }\end{array}$ & $\begin{array}{l}\text { OI } \\
\text { OVERALL }\end{array}$ \\
\hline $\begin{array}{l}\text { Turnover } \\
\text { Intention }\end{array}$ & 2,2167 & $\begin{array}{l}1,1484 \\
6\end{array}$ & 1.00000 & $\begin{array}{l}-, 224 \\
<.0001\end{array}$ \\
\hline $\begin{array}{l}\text { Organizational } \\
\text { Identification }\end{array}$ & 3,7603 &, 83339 & $\begin{array}{l}-, 224 * * \\
<.0001\end{array}$ & 1.00000 \\
\hline
\end{tabular}

As a result of the regression analysis (Table 2), it was observed that the organizational identification affected $5 \%$ of the variance of turnover intention. When the analysis results were analysed, it was seen that the organizational identification was a significant predictor of turnover intention $\left(R=-0,224 R^{2}=\right.$ $0,050 \mathrm{~F}=14.33, \mathrm{p}<0,001)$. Accordingly, it was seen that organizational identification had a significant impact on turnover intention $(B=-0,308 ; p<0001)$ and explained the variance at a rate of $5 \%\left(\mathrm{R}^{2}=0.050\right)$. In the light of these data, it can be suggested that organizational identification was a weak and significant predictor of turnover intention. It can be stated that $5 \%$ of the total variance related to turnover intention was explained by organizational identification. Therefore, $\mathrm{H} 2$ hypothesis was accepted.

Table 2: Regression Analysis

\begin{tabular}{|l|l|l|}
\hline Independent Variable & \multicolumn{2}{|l|}{ Dependent Variable } \\
\hline \multirow{5}{*}{ Organizational Identification } & Turnover \\
\cline { 2 - 3 } & $\mathbf{B}$ & Sig \\
\cline { 2 - 3 } &,- 308 & $<.0001$ \\
\cline { 2 - 2 } & $\mathrm{R}^{2}=0.050$ \\
& $\mathrm{~F}=14,331$ \\
\hline
\end{tabular}




\section{DISCUSSION AND CONCLUSION}

In this study, it is aimed to determine the relationship between the organizational identification and turnover intention for the employees in the hospitality and travel industry. For this purpose, in the current study, analyses were conducted to determine the correlation between organizational identification and turnover intention in the hospitality and travel establishments operating in Antalya. As a result of the correlation analysis, it was determined that there was a significant and negative relationship between organizational identification and turnover intention at the level of $(r=-.0,224)$ in the tourism establishments that took part in the study. In addition, the research shows that the organizational identification had a significant effect on turnover intention $(\beta=-0,308 ; \mathrm{p}<0001)$ and was explanatory at $5 \%(\mathrm{R} 2=$ 0.050). The results of the present study are consistent with the findings of the studies conducted on different sectors in the literature (Van Knippenberg and Van Schie 2000, Lee 1971, Cole and Bruch 2006, Bamber and Iyer 2002, Becker 1992, Mael and Ashforth 1995, Wan Huggins et al., 1998, Scott et al. 1999, Van Dick et al., 2004).

As it is known, the most important source of the organization that the establishments has centred on in recent years is human and their behaviours within the organization. One of the most important factors in achieving organizational efficiency is a thorough analysis of the socio-psychological factors that affect the behaviours of employees. One of the important psychological factors that affect the employees' behaviours is their level of organizational identification. Ensuring or increasing the organizational identification in establishments will enable employees to develop a strong link with their work and others by increasing their efforts to coordinate their own beliefs and workplace values. In other words, it will highlight the strong relationships they will develop with the establishment. Similarly, it is extremely important to ensure that the employees remain in the organization for the human resource to provide a competitive advantage to the establishments in the tourism sector. Turnover is one of the main problem areas of the tourism sector (Pelit et al., 2016; Erdem et al., 2015). Tourism is a satisfaction and saturation activity, and at the same time it is a sector that greatly benefits from human labour. People need to perceive their work environment positively to provide the best service to other people. An important aspect of organizational identification is that the psychological proximity of the individual to the organization expresses much more than the interpersonal relations. When we consider a person in the organization as a psychological fact, organizational identification will allow the individual to embrace the organization voluntarily and remain faithful to that organization. 
As summary, this research provides information about the level of organizational identification of the employees working in the hospitality and travel establishments operating in the province of Antalya, and its impact on their turnover intention. It is believed that the obtained results will provide important information to the sector practitioners. Increasing the practices to increase organizational identification will hinder employees' turnover intention. Business managers need to question which factors will provide the organizational identification of the employees, and what kind of individual and organizational results could be caused by organizational identification.

The most important limitation of the study is that the research was conducted only in Antalya and the results could not be generalized to the employees in other provinces. Conducting this research in different provinces with broader groups of participants will enrich the literature of organizational identification and turnover intention. Furthermore, other emotion-based variables that may affect turnover intention can be examined by researchers in future studies.

\section{REFERENCES}

- Akgündüz, Y. and Bardakoğlu, Ö. (2016). "The impacts of perceived organizational prestige and organization identification on turnover intention: the mediating effect of psychological empowerment". Journal Current Issues in Tourism, 20(14), 1510-1526.

- Aslan, Z. and Etyemez, S. (2015). "İşgörenlerin Tükenmişlik Düzeylerinin İşten Ayrılma Niyeti Üzerine Etkisi: Hatay'daki Otel İşletmelerinde Bir Araştırma". İşletme Araştırma Dergisi, 7(3), 482-507.

- Bamber, E. M., and Iyer, V. M. (2002). "Big 5 auditors' professional and organizational identification: Consistency or conflict? Auditing": A Journal of Practice \& Theory, 21(2), 21-38.

- Bartlett, K. R. (1999). The Relationship between Training and Organizational Commitment In The Health Care Field. The Degree of Doctor of Philosophy, The University of Illınois, Urbana.

- Başar, U. and Basım, N. (2015). "Effects of Organizational Identification on Job Satisfaction: Moderating Role of Organizational Politics". Yönetim ve Ekonomi, 22(2), 663-683. 
- Bayarçelik, E. B. and Fındıklı, M. (2017). "İş Tatminin, Örgütsel Adalet ve İşten Ayrılma Niyeti İlişkisindeki Aracılık Rolü”. BUJSS, 10(1), 16-31.

- Becker, T. E. (1992). "Foci and Bases of Commitment: Are they distinctions worth making?" Academy of Management Journal, 35(1), 232-244.

- Bıyık, Y. and Sökmen, A. (2016). "Örgütsel Bağl1lık, Örgütsel Özdeşleşme, Kişi-Örgüt Uyumu ve İş Tatmini İlişkisi: Bilişim Uzmanlarına Yönelik Bir Araştırma". Biliş̧im Teknolojileri Dergisi, 9(2), 221-227.

- Buchanan, B. (1974). "Building Organizational Commitment: The Socialization of Managers in Work Organizations". Administrative science quarterly, 19(4), 533-546.

- Cammann, C., Fichman, M., Jenkins, D., and Klesh, J. (1979). The Michigan Organisational Assessment Questionnaire. Unpublished manuscript, University of Michigan, Ann Arbor, Michigan.

- Cole, M. and Bruch, H. (2006). "Organizational Identity Strength, Identification, and Commitment and their Relationships to Turnover Intention: Does Organizational Hierarchy Matter?". Journal of Organizational Behavior, 27 (5), 585-605.

- Ehtiyar R., Ömüriş E. and Alan Aktaş A. (2010). “ Algılanan Stresin İşten Ayrılma Niyeti Üzerine Etkisi: Seyahat Acantası Örneği” 1. Turizmde İnsan Kaynakları Gelişimi Sempozyumu Bildiri Kitabı, 30.

- $\quad$ Erdem, B., Gülcan, B., Tokmak, C., Asanova, K., and Margaziyeva, N. (2015). "Kırgızistan Konaklama Sektöründe İnsan Kaynakları Profili Araştırması". Manas Sosyal Araştırmalar Dergisi, 4(3), 69-92.

- Güçer E., Pelit, E., Demirdağ, Ş. A. and Keleş, Y. (2017). "Sosyal Kaytarmanın İşten Ayrılma Niyeti Üzerindeki Etkisi: Otel İşletmelerinde Bir Araştırma". İşletme Araștırma Dergisi, 9(2), 14-36.

- Gül, H., Oktay, E. and Gökçe, H. (2008). "İş Tatmini, Stres, Örgütsel Bağlllık, İşten Ayrılma Niyeti ve Performans Arasındaki İlişkiler: Sağlık Sektöründe Bir Uygulama". Akademik Bakış, 15, 1-11. 
- Kesen, M. (2016). "Çalışan Katılımı, Yönetimin Açıklı̆̆ı, Örgütsel Özdeşleşme ve Çalışan Performansı Arasındaki Etkileşimleri Belirlemeye Yönelik Ampirik Bir Çalışma”. EKEV Akademi Dergisi, 66, 463-482.

- Lambert, E. G., Hogan, L. G. and Barton, S. M. (2001). "The Impact of Job Satisfaction on Turnover Intent: A Test of A Structural Measurement Model Using A National Sample of Workers". The Social Science Journal, 38, 233250.

- Lee, Sang M. (1971). "An Empirical Analysis of Organizational Identification”. Academy of Management Journal 14 (2), 213-226.

- Mael, F. A., and Ashforth, B. E. (1995). "Loyal from Day One: Biodata, Organizational Identification, and Turnover among Newcomers". Personnel Psychology, 48, 309-333.

- Onay, M., and Kılcı, S. (2011).” İş Stresi ve Tükenmişlik Duygusunun İşten Ayrılma Niyeti Üzerine Etkileri: Garsonlar ve Aş̧̧ıaşılar". Organizasyon ve Yönetim Bilimleri Dergisi, 3(2), 363-372.

- Ömüriş E. (2014).“İşyerinde Arkadaşlık İlişskilerinin Temel Belirleyicileri ve Örgütsel Sonuçlar Üzerine Etkisi” Yayımlanmamış Doktora Tezi, Turizm İşletmeciliği ve Otelcilik Anabilim Dalı. Antalya.

- Örücü, E. and Özafşarlıoğlu, S. (2013). "Örgütsel Adaletin Çalışanların İșten Ayrılma Niyetine Etkisi: Güney Afrika Cumhuriyetinde Bir Uygulama". Mustafa Kemal Üniversitesi Sosyal Bilimler Enstitüsü Dergisi, 10(23), 335-358.

- Pelit, E., Güçer, E., and Demirdağ, Ş. A. (2016). "Kadın İşgörenlerin Karşılaştı̆̆ Sorunların İş Bırakma Eğilimlerine Etkisi: Otel İşletmelerinde Bir Araştırma". Mehmet Akif Ersoy Üniversitesi Sosyal Bilimler Enstitüsü Dergisi, 8(15), 43-65.

- Polat, M. And Meyda, C. H. (2011). "Örgüt Kültürü Bağlamında Güç Eğilimi ve Örgütsel Bağl1lık İlişkisinde Örgütsel Özdeşleşmenin Aracılık Rolü”. Atatürk Üniversitesi İktisadi ve İdari Bilimler Dergisi, 25(1), 153-170.

- Polat, M. and Tabak, A. (2009). "Örgütsel Özdeşleşme Öncülleri ve Ardılları Üzerine Bir Araştırma”. KHO Bilim Dergisi, 19(1), 18-48. 
- Price, J. L. (1977). The Study of Turnover. Ames, IA: Iowa State University Press.

- Rockmann K. W. and Ballinger G. A. (2017). "Intrinsic Motivation and Organizational Identification among On-Demand Workers". Journal of Applied Psychology, 102(9), 1305-1316.

- Rusbelt, C. E., Dan, F., Glen, R. and Arch, M. G. (1988), "Impact of Variables on Exit, Voice, Loyalty and Neglect: An Integrative Model of Responses to Declining Job Satisfaction", Academy of Management Journal, 31(3), 599-627.

- Sabuncuoğlu, E. T. (2007). "Eğitim, Örgütsel Bağll1ık ve İşten Ayrılma Niyeti Arasındaki İlişkilerin İncelenmesi”. Ege Academic Review, 7(2), 613-628.

- Schwepker, C. H. (2001), "Ethical Climate's Relationship to Job Satisfaction, Organizational Commitment, and Turnover intention in the Salesforce", Journal of Business Research, 54(1), 39-52.

- Scott, C.R., Connaughton, S.L., Diaz-Saenz H.R., Katheryn M., Ruben, R., Brian, R., Sandra, P. S. and Diana, M.(1999). "The Impacts of Communication and Multiple Identifications on Intent to Leave". Management Communication Quarterly, 12(3), 400-435.

- Serçeoğlu, N., Iş̧k, Z. and Çetinkaya, M. Y. (2016). "Işyeri Zorbalığının İşten Ayrılma Niyeti Üzerine Etkisi: Konaklama İşletmelerinde Çalışan Personel Üzerine Bir Araştırma”. Uluslararası Sosyal Araștırmalar Dergisi, 9 (45), 10991109 .

- Şantaş, F., UĞURLUOĞLU, Ö., Kandemir, A. ve Çelik, Y. (2016). "Sağlık Çalışanlarında Örgütsel Sinizm, İş Performansı ve Örgütsel Özdeşleşme Düzeyleri Arasındaki İlişkilerin İncelenmesi”. Gazi Üniversitesi, İktisadi İdari Bilimler Dergisi, 18(3), 867-886.

- Tavşancil, E. (2002). Tutumların ölçülmesi ve spss ile veri analizi. Ankara, Nobel Yayincilik.

- Tett, R. P. and Meyer, J. P. (1993). "Job Satisfaction, Organizational Commitment, Turnover Intention, and Turnover: Path Analyses Based on MetaAnalytic Findings". Personnel Psychology 46(2), 259-293. 
- Tolukan, E., Şahin, M. Y. and Koç, M. (2016). "Jimnastik Antrenörlerinin Örgütsel Özdeşleşme Düzeyleri ve İşten Ayrılma Niyeti İlişkisi”. 11(8), 377398.

- Tosun, M. (1981). "Örgütsel Etkililik, Türkiye ve Ortadoğu”. Amme İdaresi Enstitüsü Yayınları 196.

- Turgut, H., Soran, S. and Ateş, M. F. (2017). "Örgütsel Özdeşleşme İşten Ayrılma Niyeti İlişkisinde Psikolojik Dayanıklılığın Aracı Rolü”. 16. Ulusal İsletmecilik Kongresi, 577-592.

- Turunç, Ö. and Çelik, M. (2015). "Örgütsel Özdeşleşme ve Kontrol Algılamalarının, Çalışanların İșten Ayrılma Niyeti ve İş Performansına Etkileri”. Atatürk Üniversitesi İktisadi ve İdari Bilimler Dergisi, 24(3), 163-181.

- Tüzün, İ.K. (2006). "Örgütsel Güven, Örgütsel Kimlik ve Örgütsel Özdeşleşme İlişkisi; Uygulamalı Bir Çalışma”. Yayımlanmamış Doktora Tezi, Gazi Üniversitesi Sosyal Bilimler Enstitüsü, Ankara.

- Van Dick, R., Christ, O., Stellmacher, J., Wagner, U., Ahlswede, O., Grubba, C., and Tissington, P. A. (2004). "Should I stay or Should I go? Explaining Turnover Intentions with Organizational Identification and Job Satisfaction". British Journal of Management, 15(4), 351-360.

- Van Knippenberg, D. and Van Schie, E. C. (2000). "Foci and Correlates of Organizational Identification”. Journal of Occupational and Organizational Psychology, 7(3), 137-147.

- Vardaman, J. M., Allen, D. and Rogers, B. Y. (2018). "We Are Friends but Are We Family? Organizational Identification and Nonfamily Employee Turnover". Entrepreneurship Theory and Practice 42(2), 290-309.

- Wan-Huggins, V. N., Riordan, C. M., \& Griffeth, R. W. (1998). "The Development and Longitudinal Test of A Model of Organizational Identification”. Journal of Applied Social Psychology, 28(8), 724-749.

- Yenihan, M., Ömer M. and Çiftyıldız, K. (2014). "İ̉ş Stresi ve İşten Ayrılma Niyeti Arasındaki İlişki: Otomotiv İş̧letmesinde Bir Araştırma”. Çalışma İlişkileri Dergisi, 5(1), 38-49 